\title{
Soft resilience: moisture-dependent lichen elasticity buffer herbivore trampling in cold alpine-tundra ecosystems
}

\author{
Jan Heggenes ${ }^{1} \cdot$ Christian Fagertun $^{2} \cdot$ Arvid Odland $^{1} \cdot$ Dag K. Bjerketvedt $^{1}$
}

Received: 3 June 2019 / Revised: 14 April 2020 / Accepted: 26 May 2020 / Published online: 7 June 2020

(c) The Author(s) 2020

\begin{abstract}
Herbivores may have extensive top-down effects in open grazing ecosystems, generating vegetation changes by grazing and trampling. Trampling effects are understudied, but may be a major ecological factor. In cold alpine-Arctic ecosystems grazing and trampling by wild tundra reindeer (Rangifer tarandus) may be particularly important in lichen-dominated heaths. Dry lichen are crushed by trampling, and it is estimated that volume loss of lichen trampled may be considerably larger than lichen volume eaten by reindeer. Humidity affects lichen pliability and elasticity, and thereby resilience to trampling. Although crucial for estimating lichen vegetation trampling loss, the relationship between humidity and lichen elasticity is not well known. We collected samples of three lichen species in natura and in factorial experiments tested effects of species, levels of humidity $(25,70,80,90$ and $100 \% \mathrm{RH})$ and temperatures $\left(5\right.$ and $\left.25^{\circ} \mathrm{C}\right)$, on resilience to trampling (pressure resistance). The humidity:species interaction was the strongest factor increasing pressure resilience with increasing humidity, whereas temperature had small or no effects. Lichen elasticity increased rapidly above 70\% RH. Consequently, when estimating lichen resources and potential trampling loss, number of dry days (less than $70 \% \mathrm{RH}$ ) should be estimated. This also has important ramifications for effects of climate change on the sustainability of reindeer populations.
\end{abstract}

Keywords Trampling $\cdot$ Lichen $\cdot$ Resilience $\cdot$ Humidity $\cdot$ Elasticity

\section{Introduction}

Herbivores may have extensive top-down effects in opengrazing ecosystems, e.g. alpine and tundra areas, generating vegetation responses and changes via their grazing and trampling (e.g. Cumming and Cumming 2003; Rosenthal et al. 2012; Holtmeier 2015; Heggenes et al. 2017). "Grazing" consists of eating, but also the necessarily associated trampling of vegetation, i.e. two different ecological processes (e.g. Rosenthal et al. 2012; Lezama and Paruelo 2016; Mudongo et al. 2016). The effects of trampling on vegetation may differ from those associated with grazing, with respect to the magnitude and quality of vegetation changes. Unfortunately, effects of trampling are understudied relative to grazing, even though some studies suggest trampling per se

Jan Heggenes

Jan.Heggenes@usn.no

1 Department of Natural and Environmental Health Sciences, University of South Eastern Norway, B $\emptyset$, Telemark, Norway

2 Department of Wildlife Ecology, Inland University College, Evenstad, Norway may be a major ecological factor (e.g. Cumming and Cumming 2003; Ludvikova et al. 2014; Pekkarinen et al. 2017).

In cold alpine-Arctic ecosystems negative effects of trampling on vegetation are likely to be effected by the large, mammalian herbivore wild tundra reindeer (Rangifer taran$d u s$ ) when both grazing - and trampling - the different species of lichen (Danell et al. 1994; Kumpula 2001; Heggenes et al. 2017) typically important in alpine-Artic ecosystems (Crittenden 2000; Odland et al. 2018). In Norwegian wild reindeer areas lichen may constitute $1-33 \%$ of the vegetation $(n=21)$, and on exposed snow-poor (chionophobic) ridges often more than 50\% (Kjørstad et al. 2017) Reindeer is one of few species that are able to digest lichen, and may feed on lichen throughout the year, but particularly in winter (Skogland 1984; Kojola et al. 1995; Nellemann 1996; Storeheier et al. 2002). The poikilohydric lichen become dry and brittle in dry weather, and therefore, particularly susceptible to trampling. Indeed, volume loss of lichen trampled by reindeer may be even larger than lichen volume eaten (Heggenes et al. 2017). However, it has also been noted that humidity affect lichen pliability and elasticity (Matwiejuk 2000; Heggenes et al. 2017). Increasing humidity may therefore 
moderate the negative trampling effects via conferring resilience to trampling damage and volume loss. Notably, climate predictions state that the near-future climate will be both warmer and wetter for wild reindeer areas in Western Europe (Hanssen-Bauer et al. 2009). This may have important consequences for lichen, including their elasticity and thereby susceptibility to trampling. Therefore, we set out to explore this relationship, including contrasting high-low temperatures, representing different seasons.

Previous studies have suggested that humidity is an important factor determining lichen elasticity. On an anecdotal basis, Hirsch et al. (1911) stated more than a hundred years ago, that if reindeer trample on dry and brittle lichen, it will be destroyed, with the results that regrowth stops. Pegau (1970) attempted to quantify how much damage trampling by reindeer caused the lichen pastures by herding 500 reindeer over pastures both wet and dry. Lichen dislodged and fragmented more on dry than rainy days, though it was concluded that the effects of dislodging were not fully understood. Heggenes et al. (2017) systematically demonstrated the major effects of trampling in dry lichen, but noted that more studies are required to explore the relationship between air humidity, lichen elasticity and trampling resilience. Whereas dry lichen is likely to be completely crushed by trampling, saturated wet lichen appears to recover from trampling very well (Heggenes et al. 2017). Here we investigate the relationship between air humidity and lichen elasticity.

To explore this, we designed a series of factorial experiments with lichen species, relative humidity $(\% \mathrm{RH})$ and temperature $\left({ }^{\circ} \mathrm{C} \mathrm{T}\right)$ as factors, and resistance to simulated trampling as the response variable. The working hypotheses were: (a) there are species differences, depending on growth form, (b) humidity has an initially strong effect on elasticity, but (c) temperature has little effect.

\section{Materials and methods}

Lichen consists of many species, but only a few groundgrowing species, are important to alpine-Arctic reindeer, particularly in winter, as ground lichen are abundant on elevated ridges with little snow. The most important lichen forage belongs to the families Cladonia and Flavocetraria, typically Flavocetraria nivalis, Cladonia rangiferina and sister-species Cladonia arbuscula, and Cladonia stellaris, growing in a top-down gradient on ridges (Gaare and Skogland 1975; Skogland 1984; Danell et al. 1994; Kjørstad et al. 2017).

\section{Field sampling}

Fifty square $(16 \times 16 \mathrm{~cm})$ samples each of three important species of lichen were collected randomly and in natura: C. stellaris, $C$. rangiferina and $F$. nivalis. All samples were from extensive, natural and ungrazed lichen mats in eastern Norway (Stor-Elvdal municipality) and at two different locations: from a pine (Pinus sylvestris) forest ecosystem (Evenstad train station; 276 Masl; Euref89UTM33: 6816352N292250E) for C. stellaris and C. rangiferina, collected 19.05.2017, and a higher elevation alpine ecosystem (Birkerbeinervegen; 1021 Masl; Euref89UTM33: $6810371 \mathrm{~N}, 279049 \mathrm{E}$ ) for $F$. nivalis, collected 18.09.2017. Sampled $C$. stellaris and $C$. rangiferina lichen mats were all ungrazed and untrampled, as this location is not within any wild or domestic reindeer area, and no other domestic animals had grazed there. The area occupied by $F$. nivalis may have been lightly grazed as this location is within a wild reindeer area, but there was no sign of trampling and grazing prior to or during sampling, e.g. tracks or faeces, and the location is not frequently used by wild reindeer. Natural lichen mat thickness varies between species, as they have different growth-forms and grow in different habitats (e.g. Crittenden 2000). The mean thickness of collected samples (measured in the sample center and center of 4 corner subsquares) was less for $F$. nivalis $(54.87 \mathrm{~mm} \pm \mathrm{SD} 8.24, n=49)$ than for $C$. rangiferina $(87.48 \mathrm{~mm} \pm \mathrm{SD} 9.06, n=50)$ and $C$. stellaris $(84.96 \mathrm{~mm} \pm \mathrm{SD} 9.74, n=50)$, which did not differ (ANOVA, $F_{2,146}=198.6, p<0.001$, Tukey post hoc tests, $p<0.0001$, resp. $p=0.346$ ).

A lichen mat sample was cut to size by first placing a square $16 \times 16 \mathrm{~cm}$ stainless steel sampling frame on top of the lichen mat. A thin, sharp knife was then used to cut along the edges of the sampling frame, and underneath close to the soil to include any decaying basal part of the lichen. Fifty samples of each lichen species were collected for experimental purposes, dried at room temperature, and stored at ambient indoor temperatures in square plastic boxes measuring $W=L=18.2 \times D=10.7 \mathrm{~cm}$. (Table 1). Two months before experiments started, all samples were moved to a climatecontrolled room with controlled temperature at $25{ }^{\circ} \mathrm{C}$ and ambient relative air humidity (RH) $25-30 \%$.

\section{Experimental study design}

Experiments were conducted using a factorial study design with three factors, (a) lichen species (three levels), (b) temperature (two levels), and (c) relative humidity (five levels). Measured pressure (in grams; proxy for 'trampling weight') was the continuous response variable at consecutive 'trampling depths' $(5,10,15,20,25$ and $30 \mathrm{~mm})$. The first contrasting temperature level of $25{ }^{\circ} \mathrm{C}$ was considered 
Table 1 Experimental factorial (lichen species, temperature, humidity) study design and testing order: the three different lichen species, total number of samples, number of samples per two levels of temperature $\left({ }^{\circ} \mathrm{C}\right)$, and number of samples per five levels of humidity (RH \%)

\begin{tabular}{|c|c|c|c|c|c|}
\hline Species & $\begin{array}{l}\text { Total \# sam- } \\
\text { ples/trials }\end{array}$ & $\begin{array}{l}\text { Sample size }(n) \\
\text { temperature }\end{array}$ & $\begin{array}{l}\text { Temperature } \\
\left({ }^{\circ} \mathrm{C}\right)\end{array}$ & $\begin{array}{l}\text { Sample size }(n) \\
\text { humidity }\end{array}$ & $\begin{array}{l}\text { Humidity } \\
\text { (RH \%) }\end{array}$ \\
\hline \multirow[t]{10}{*}{ Cladonia stellaris } & \multirow[t]{10}{*}{50} & \multirow[t]{5}{*}{25} & \multirow[t]{5}{*}{5} & 5 & 25 \\
\hline & & & & 5 & 100 \\
\hline & & & & 5 & 70 \\
\hline & & & & 5 & 80 \\
\hline & & & & 5 & 90 \\
\hline & & \multirow[t]{5}{*}{25} & \multirow[t]{5}{*}{25} & 5 & 25 \\
\hline & & & & 5 & 100 \\
\hline & & & & 5 & 70 \\
\hline & & & & 5 & 80 \\
\hline & & & & 5 & 90 \\
\hline \multirow[t]{10}{*}{ Flavocetraria nivalis } & \multirow[t]{10}{*}{50} & \multirow[t]{5}{*}{25} & \multirow[t]{5}{*}{5} & 5 & 25 \\
\hline & & & & 5 & 100 \\
\hline & & & & 5 & 70 \\
\hline & & & & 5 & 90 \\
\hline & & & & 5 & 95 \\
\hline & & \multirow[t]{5}{*}{25} & \multirow[t]{5}{*}{25} & 5 & 25 \\
\hline & & & & 5 & 100 \\
\hline & & & & 5 & 70 \\
\hline & & & & 5 & 90 \\
\hline & & & & 5 & 95 \\
\hline \multirow[t]{10}{*}{ Cladonia rangiferina } & \multirow[t]{10}{*}{50} & \multirow[t]{5}{*}{25} & \multirow[t]{5}{*}{5} & 5 & 25 \\
\hline & & & & 5 & 100 \\
\hline & & & & 5 & 70 \\
\hline & & & & 5 & 80 \\
\hline & & & & 5 & 90 \\
\hline & & \multirow[t]{5}{*}{25} & \multirow[t]{5}{*}{25} & 5 & 25 \\
\hline & & & & 5 & 100 \\
\hline & & & & 5 & 70 \\
\hline & & & & 5 & 80 \\
\hline & & & & 5 & 90 \\
\hline
\end{tabular}

representative of a warm summer day in the alpine environment when e.g. trampling may be a major concern. The second level was chosen to represent ambient temperatures during the seasonal transition periods in autumn and spring seasons and $5{ }^{\circ} \mathrm{C}$ usually defines the temperature threshold for the alpine growing season length (Kudo 1991). However, lichen can grow at lower temperatures (Skree 1975; Klein and Shulski 2011), depending on wet thallus (e.g. Jonsson Čabrajič et al. 2010). The third factor, relative humidity, had five levels; 25, 70, 80, 90, and 100\% humidity, based on pilot experiments and results in Heggenes et al. (2017), which suggested more pronounced changes in lichen elasticity at higher levels of humidity. They also suggested a potentially weaker elasticity response at lower levels of humidity for F. nivalis. Therefore, this species was tested at levels of 25 , $70,90,95$ and $100 \%$ RH. For each combination of factor and level, i.e., $3 \times 2 \times 5=30$ combinations, we ran five replicates, amounting to 150 samples/trials, i.e. 50 samples of each lichen species (Table 1).

To our knowledge this is the first experiment of its kind, so we had to design an instrument for testing and measuring 'trampling pressure'. A reindeer's hoof was represented by a $10.5 \mathrm{~cm}$ diameter circular piece of plywood, corresponding to the approximate circumference of an actual female reindeer hoof. This proxy hoof was fixed to a $24.1 \mathrm{~cm}$ long, $5 \mathrm{~mm}$ diameter round steel rod, resting on a $65 \mathrm{~cm}$ high table with an iron frame and $3 \mathrm{~cm}$ thick wood tabletop measuring $W=26 \times L=52.5 \mathrm{~cm}$. For the table to be more stable, an additional wood plate was attached to the bottom of the table legs. Before each experiment, the square plastic box containing the lichen sample was placed on the tabletop and held in place by a square wood frame (inner 
$L=W=18 \mathrm{~cm}$ fitting the plastic box). A $13 \mathrm{~mm}$ diameter hole was drilled through the tabletop at the center of this square, and with a corresponding hole through the bottom of each sample plastic box. The holes were used to carefully center the 'hoof' steel rod, down through the sample lichen mat and through the holes in the box and tabletop. To stabilize the steel rod and minimize friction, the tabletop hole was fitted with a $7.5 \mathrm{~cm}$ long copper tube running through the tabletop and $4.5 \mathrm{~cm}$ down below the bottom of the tabletop. To measure at any time how deep the proxy hoof was pressed down into the lichen mat, an aluminum ruler was attached to the copper tube and the bottom of the tabletop. Pressure was measured by attaching scales to the end of the 'hoof' steel rod, and manually exerting pressure. Two different scales (Salter Super Samson; https://www. salter.com.au/salter-super-samson-5kg-scale) were fitted depending on relevant pressure required, effectively $\% \mathrm{RH}$ (below). The top end of the scale was connected to the low end of the rod by a hook. The bottom end of the scale was attached to the bottom table via a nylon pull strap, used to easily and evenly exert the required 'trampling' pressure. A red mark on the metal rod, and relative to the ruler, permitted measurement of trampling depth $(\mathrm{mm})$ corresponding to exerted pressure $(5 \mathrm{~g})$.

\section{Experimental protocol}

All samples were divided into trials by factors (Table 1). Samples were acclimatized in a controlled environment $\left({ }^{\circ} \mathrm{C}\right.$ and $\% \mathrm{RH}$ ) for minimum $24 \mathrm{~h}$. Based on pilot experiments, we first tested at $25^{\circ} \mathrm{C}$ for three lichen species and five levels of humidity, i.e. $25,100,70,80,90 \%$ RH (respectively 95\% for F. nivalis, Table 1) with five replicates in each trial. This procedure was repeated at $5{ }^{\circ} \mathrm{C}$. For the $100 \%$ RH tests, samples were soaked in water for $10 \mathrm{~min}$ immediately prior to testing. For all intermediate RH levels ranging from 70 to $95 \%$, samples were left to acclimatize $(24 \mathrm{~h})$ in an environmental chamber (Termaks KBP 6395; https://www.terma ks.com/products/environmental-chambers/) which permits control of both temperature and RH. As a precaution, $\mathrm{RH}$ was also independently measured using a separate logger (Testo Saveris 2; https://www.testo.com/en-US/products/ saveris-2). As it turned out, the cabinet did not provide RH at the highest humidity. Therefore, we used an additional ultrasonic cleaner (VWR USC300TH; https://uk.vwr.com/ store/product/10694225/ultrasound-cleaning-baths-usc) and additional containers filled with water, to establish the desired level of RH.

Samples were removed from the environmental chamber and immediately tested one by one, then caped with a lid, to avoid any drying out of individual samples during testing procedures.
All samples were weighed $(0.1 \mathrm{~g})$ prior to acclimatization, and again after $24 \mathrm{~h}$, immediately prior to testing, to quantify by weight the amount of water absorbed by the lichen. After weighing, the 'hoof' steel rod was inserted through the lichen. With the proxy hoof lightly resting on top of the lichen mat, the scale was connected by the hook to the low end of the rod. The red mark on the rod was reference start point.

To have data representing different reindeer 'trampling weights', exerted pressure was systematically measured at standardized interval levels of 'trampling depths': 5, 10, 15, 20,25 and $30 \mathrm{~mm}$. Some samples resisted maximum pressure, especially during the trials of dry lichen, i.e. the $25 \%$ $\mathrm{RH}$. The maximum trampling depths could not be reached for 37 samples, because the scale bottomed out at the maximum pressure of $15 \mathrm{~kg}$. If so, the maximum depth into the lichen mat of the proxy hoof was noted. A $15 \mathrm{~kg}$ pressure corresponded to $174 \mathrm{~g} \mathrm{~cm}^{-2}$, near the upper limit of normal trampling weights for reindeer $\left(180 \mathrm{~g} \mathrm{~cm}^{-2}\right)$ (Merkgren 1971). In case there were any remaining trampling depths that could not be tested, for the above reason, a proxy value of $20 \mathrm{~kg}$ pressure was used for further analysis.

In five of the tests of dry lichen, the lichen sample exhibited a sudden collapse, with corresponding sudden drop in measured trampling depth, meaning that accurate in-between measurements could not be made. In these cases, we interpolated values for exerted trampling pressure.

When the final trampling depth was reached, strap tension was released, and the scale removed. To measure speed and amount of potential lichen volume recovery, a stopwatch was immediately started and recovery measured, i.e. regained volume with time. These measurements were: immediately, after 2, 5 and 15 min (Heggenes et al. 2017).

$R$ version 2.14.2 (Venables and Smith 2012) was used for statistical analyses on $\ln$-transformed response pressure raw data, which tended to be somewhat skewed towards high/low values. Models across all combinations and interactions of the prediction variables (humidity, lichen species, temperature) were compared using an information-theoretic model approach with a correction for finite sample size (AICc) (Akaike 1974; Burnham 2002). Models which included additional parameters, but were within 2 AIC units of the top ranking model, were considered to not contain additional information (Arnold 2010). AICc, $\triangle$ AICc, Akaike's weights $(=w)$ and $\log$ likelihood were calculated, as were the across the response variable pressure's different depth levels, using the package "AICcmodavg" in R (Mazerolle 2017). We considered models with $\triangle \mathrm{AICc}<4$, since according to Burnham (2002) models with a $\triangle \mathrm{AICc}<4-7$ are plausible models. The normally distributed regained height response data were analyzed with ANOVA fixed factor models, and repeated measures $\mathrm{t}$-tests to compare changes over time. 
Table 2 The highest ranked predictive models relative to the response variable pressure $(5 \mathrm{~g})$ at successive levels of 'trampling depth' into the lichen

\begin{tabular}{lllllr}
\hline $\begin{array}{l}\text { Pressure depth } \\
(\mathrm{mm})\end{array}$ & Fixed effects & AICc & $\Delta$ AICc & CumWi & LnL \\
\hline 5 & & & & & \\
& Temperature + Humidity:Species & 249.66 & 0 & 0.92 & -105.49 \\
10 & Null model intercept & 425.23 & 175.57 & 1 & -210.57 \\
& Temperature + Humidity:Species & 232.44 & 0 & 0.46 & -96.88 \\
& Null model intercept & 454.84 & 222.40 & 1 & -225.38 \\
15 & Temperature+Humidity:Species & 203.72 & 0 & 0.81 & -82.52 \\
& 1+Humidity:Species & 206.57 & 2.85 & 1 & -85.23 \\
& Null model intercept & 462.30 & 258.58 & 1 & -229.11 \\
20 & Temperature+Humidity:Species & 202.37 & 0 & 0.43 & -81.85 \\
& 1+Humidity:Species & 205.95 & 3.58 & 1 & -84.92 \\
& Null model intercept & 467.99 & 265.62 & 1 & -231.96 \\
25 & 1+Humidity:Species & 174.97 & 1.65 & 1 & -69.42 \\
& Null model intercept & 459.74 & 286.42 & 1 & -227.83 \\
30 & 1+Humidity:Species & 154.03 & 0.23 & 1 & -58.98 \\
& Null model intercept & 447.14 & 293.28 & 1 & -221.53 \\
\hline
\end{tabular}

The models are ranked after the smallest AICc value

Fixed effects the predictor variables, AICc the AICc score, $\triangle A I C c$ the difference between AICc for the model of concern compared to the highest ranked model, CumWi Akaike's cumulative weight, and $L n L \log$ likelihood

\section{Results}

The experiments demonstrated a consistently strong interaction effect of humidity and species on lichen elasticity (Table 2). This effect was non-linear with the strongest effect at higher relative humidity (Figs. 1,2). Temperature appeared to have a slight effect at lower pressures, but this effect was not found at higher pressures (Table 2). Thus, the consistently most informative model included the humidity:species interaction (Table 2).

\section{Lichen elasticity increase with humidity}

Pressure at 5 to $10 \mathrm{~mm}$ varied with humidity and species, and temperature (Table 2). At $25{ }^{\circ} \mathrm{C}, F$. nivalis tended to be more variable than $C$. rangiferinea and $C$. stellaris, which responded similarly (Fig. 1), except that $C$. stellaris tended to be slightly less elastic than C. rangiferina at 25 to $80 \%$ RH. At low temperatures, pressure was slightly higher $\left(5 \mathrm{~mm}\right.$ and $5{ }^{\circ} \mathrm{C}$ and $25^{\circ} \mathrm{C}$ : means $=1.16$ and $0.96 ; 10 \mathrm{~mm}$ and $5{ }^{\circ} \mathrm{C}$ and $25^{\circ} \mathrm{C}$ : means $=2.87$ and 2.42). Dry lichen, i.e. at $25 \% \mathrm{RH}$, resisted trampling pressure in all tests, but exhibited no elasticity, and would suddenly break and collapse if pressure was sufficient, making direct comparisons difficult. At higher RH, particularly at or more than $80 \%$, the increased elasticity conveyed by humidity prevented breakage.

The response pattern appeared to change gradually when pressure increased above $10 \mathrm{~mm}$. Pressure at $15-20 \mathrm{~mm}$ also varied with humidity and species, whereas temperature contributed relatively less to the model, and had no effect a higher pressures (Table 2). The factors humidity and species, via their interaction humidity:species, predicted the changing elasticity as pressure increased above 20 and up to $30 \mathrm{~mm}$ (Table 2). In particular $F$. nivalis required more pressure at $70 \% \mathrm{RH}$ or higher (Figs. 1, 2). At higher trampling pressures, response seemed to be somewhat more variable and response direction somewhat less consistent, at temperature $5{ }^{\circ} \mathrm{C}$ compared to $25^{\circ} \mathrm{C}$ (Fig. 2).

\section{Regained height}

Immediately regained height at $5{ }^{\circ} \mathrm{C}$ increased with increasing humidity $\left(F_{4.60}=6.30, p<0.001 ;\right.$ Fig. 3$)$, and a humidity:species interaction $\left(F_{8.60}=4.63, p<0.001\right)$. Although somewhat variable, $F$. nivalis tended to immediately regain slightly more height with higher humidity. For $C$. rangiferina and $C$. stellaris this trend was less pronounced at low temperature (Fig. 3). Overall trends were similar, but individual species results more variable for tests at $25{ }^{\circ} \mathrm{C}$. Again immediately regained height increased overall with humidity $\left(F_{4.59}=6.19\right.$, $p<0.001)$ with an additional effect of species $\left(F_{2.59}=3.81\right.$, $p=0.0279) . . F$. nivalis and $C$. stellaris regained more height with higher humidity, although with some variation (Fig. 3). For C. rangiferina, however, there appeared to be no such trend.

Regained height after 2 min or more, was small or insignificant, both at low and high temperature. Only after 2 min at low temperature was there a slight significant, but rather indeterminate effect of humidity, species and interaction $\left(F_{4.59}=2.83, p=0.032\right.$ and $F_{2.59}=5.75, p=0.005$ 

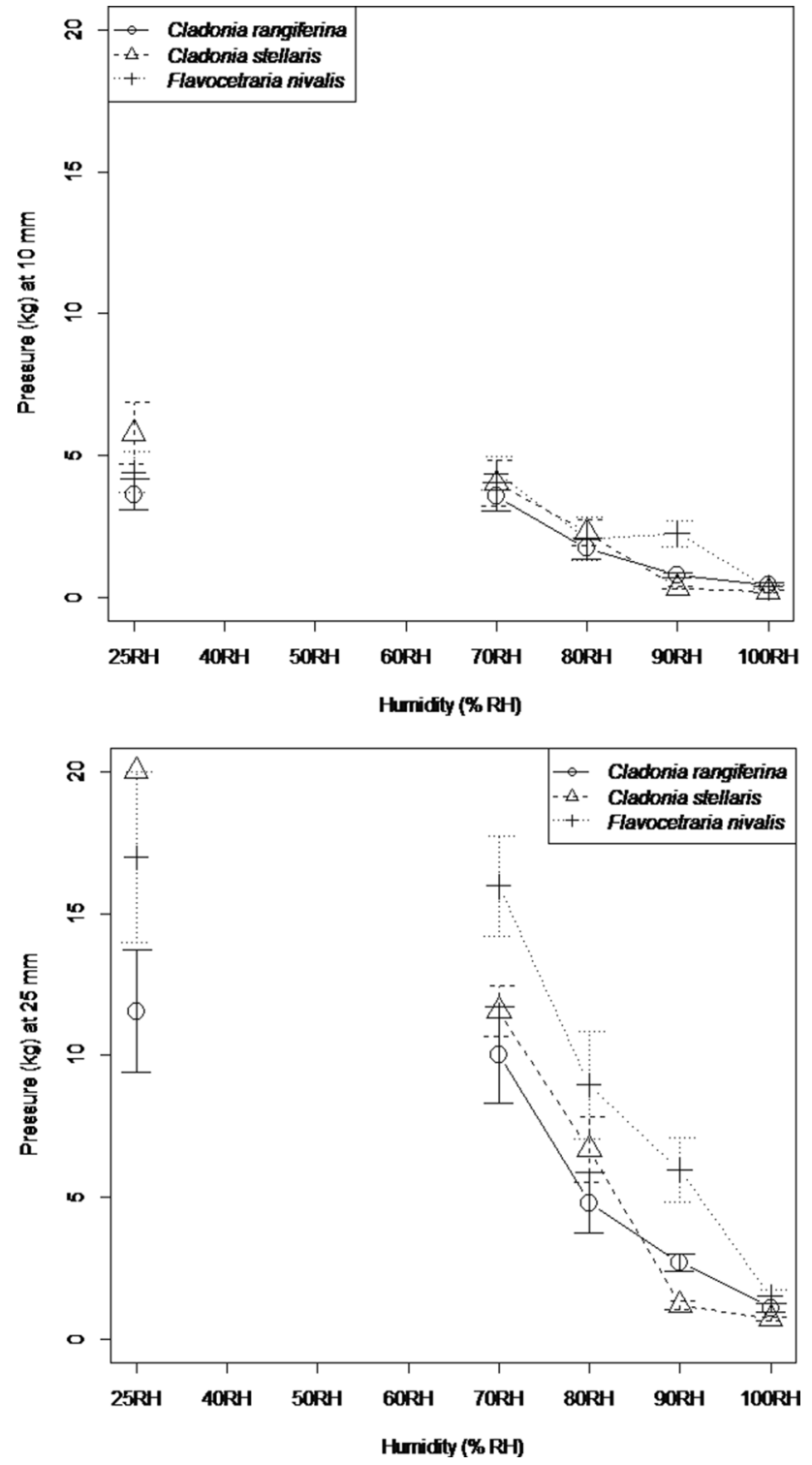

Fig. 1 Pressure (kg: mean \pm SE) at $10 \mathrm{~mm}$ (top) and $25 \mathrm{~mm}$ (bottom) trampling depth for three lichen species at different levels of humidity $(\% \mathrm{RH})$ at temperature $25^{\circ} \mathrm{C}$

and $F_{8.59}=2.57, p=0.018$, respectively) and after $15 \mathrm{~min}$ a slight effect of humidity only $\left(F_{4.59}=9.68, p<0.001\right)$. For all other tests, there were no significant effects of humidity and species on regained height $(p>0.092)$. Overall, mean regained height dropped rapidly with time. It was $10.7 \mathrm{~mm}$ more immediately vs. $2 \mathrm{~min}$. after trampling pressure release (paired $t$-test, $t_{148}=35.432, p<0.0001$ ), then dropped to $1.23 \mathrm{~mm}$ from 2 to $5 \mathrm{~min}$. (paired $t$-test, $t_{148}=11.306$, $p<0.0001)$.

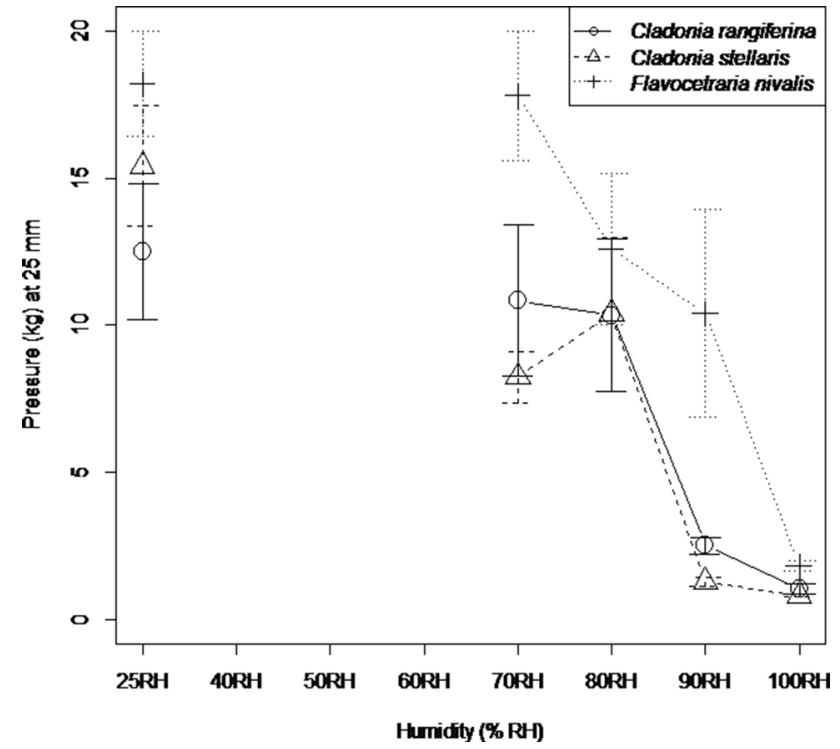

Fig. 2 Pressure (kg: mean \pm SE) at $25 \mathrm{~mm}$ trampling depth for three lichen species at different levels of humidity (\% RH) at temperature $5{ }^{\circ} \mathrm{C}$

\section{Water weight gain}

As expected, the amount of water absorbed by lichen increased with increasing humidity (Fig. 4). There was a particularly marked increase up to $100 \% \mathrm{RH}$, which likely was tied in with the different methods used. For humidity up to $95 \% \mathrm{RH}$, all samples were acclimatized in the environmental chamber. For $100 \%$ humidity, i.e. rain, we necessarily had to expose the samples to water directly. They were soaked in water and drained $10 \mathrm{~min}$ prior to testing. Thus higher gained weight of these samples probably reflect additional water adsorbed, and water droplets caught in the lichen branch structures.

\section{Discussion}

The results clearly demonstrate the major effect of humidity on lichen pliability and elasticity. Different lichen species may interact with humidity and respond somewhat differently, whereas the contrasting temperature appeared to have minor or no effect.

Tundra reindeer living in cold alpine-Arctic ecosystems is one of the very few species that have adapted to digest and use lichen as main forage for longer periods of the year (Skogland 1984; Kojola et al. 1995; Nellemann 1996; Storeheier et al. 2002), but may also have negative effects on this vegetation via trampling (Heggenes et al. 2017). Lichens may constitute major parts of the vegetation in alpine-Arctic ecosystems (Crittenden 2000; Odland et al. 2018), where 

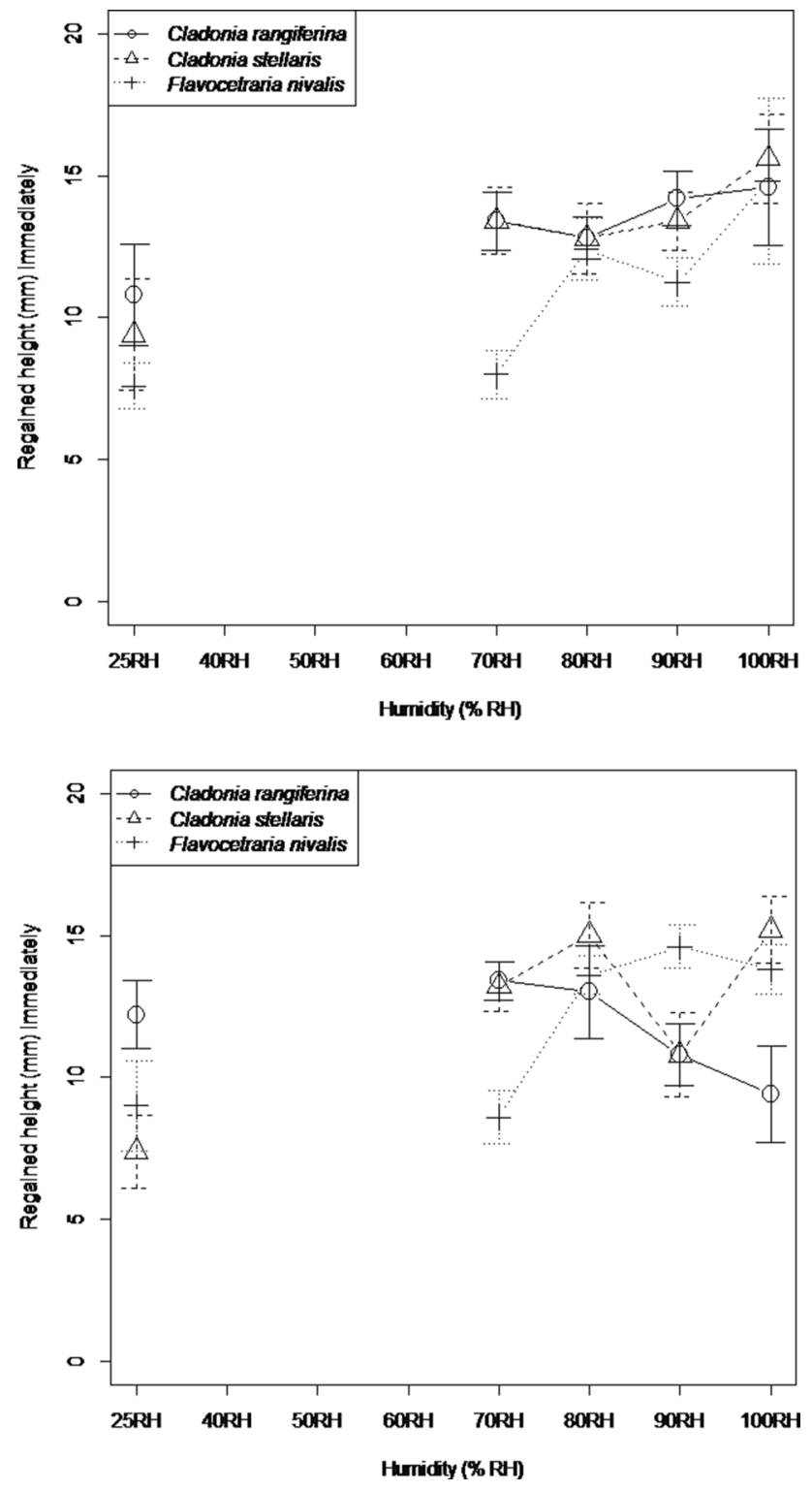

Fig. 3 Regained height $(\mathrm{mm}$ : mean $\pm \mathrm{SE})$ immediately after pressure release for three lichen species at different levels of humidity (\% $\mathrm{RH})$ at temperature $5{ }^{\circ} \mathrm{C}$ (top) and $25{ }^{\circ} \mathrm{C}$ (bottom)

they thrive and dominate vegetation in frost-prone areas with little or no snow-cover, typically exposed, wind-blown ridges (Crittenden 2000; Odland and Munkejord 2008; Bjerketvedt et al. 2015). In such habitats, lichen may be available to herbivores year round, and be particularly important in winter, when other, less exposed types of vegetation are covered in snow. The more snow-tolerant lichen species, i.e., C. stellaris, may, however, grow also in less exposed, e.g., forested, habitats, and constitute important reindeer forage here (e.g. Kumpula 2001; Jonsson Čabrajič et al. 2010). In open alpine and/or Arctic reindeer habitats, the long winter in particular limits forage availability (Nellemann 1996;

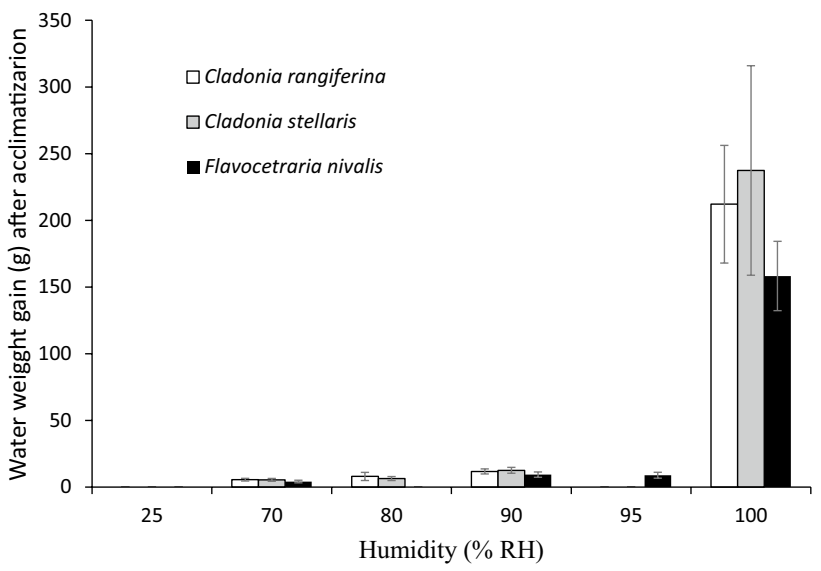

Fig. 4 Mean water weight gain (g: error bars $= \pm \mathrm{SD}$ ) at different levels of \% RH. Mean of 149 samples

Lundqvist 2003; Hansen et al. 2009). Indeed, lichen is widely considered the most important and critical winter forage for both wild and semi-domesticated reindeer (Skogland 1978; Danell et al. 1994; Falldorf et al. 2014). In Norway, lichen availability and production is considered a main factor determining the carrying capacity of wild tundra reindeer areas, and consequently determine management target population size, for example on the Hardangervidda plateau, the main wild reindeer population in Western Europe (Skogland 1984; Punsvik and Jaren 2006; Bjerketvedt et al. 2015; Kjørstad et al. 2017). It is estimated that reindeer on average eat approximately $2.1 \mathrm{~kg}$ dry lichen daily and $450-500 \mathrm{~kg}$ dry in a year (Bjerketvedt et al. 2015), but may trample even more during foraging (Gaare and Skogland 1975; Heggenes et al. 2017). Furthermore, reindeer tend to migrate between seasonal pastures (Strand et al. 2006), e.g. from winter to summer, which can also inflict more trampling damage on the pastures. Even worse, if natural seasonal migrations are hampered, notably by anthropogenic fragmentation and disturbance (Vistnes et al. 2004; Vistnes and Nellemann 2008; Nellemann et al. 2010; Skarin and Ahman 2014), reindeer may remain in winter pasture areas for extended periods of the year, generating additional trampling damage.

\section{Humidity and lichen trampling resilience}

As for other ungulate foragers, reindeer trampling may have major ecological consequences, e.g. influencing and changing quantity and quality of forage, in particular lichen (e.g. Kojola et al. 1995; Kumpula et al. 2011; Holtmeier 2015). Intensive reindeer grazing and trampling can reduce lichen mass to $10 \%$ or less of lichen mass untouched by reindeer (Kojola et al. 1995). Different from vascular plants, lichen are poikilohydric, meaning that they depend entirely on the passive physical processes of water uptake and loss 
(Blum 1973), and the amount of water in the lichen podetia ('leaves') vary near continuously with the air humidity (Matwiejuk 2000). When dry, lichen are particularly susceptible to trampling. They are brittle and easily crushed when trampled, will retain a hoof footprint after trampling, and will not recover. However, as documented here, humidity appears to play a decisive role in dictating lichen pliability and elasticity (see also e.g. Matwiejuk 2000; Jonsson Čabrajič et al. 2010; Tømmervik et al. 2012; Heggenes et al. 2017). Humidity moderate the negative trampling effects via conferring increasing resilience to trampling damage and volume loss. Even though this relationship is crucially important for modeling and predicting potential trampling loss, it is not well studied, and generally modeled as a simple, fixed factor (Moxnes et al. 2001; Tahvonen et al. 2014; Pekkarinen et al. 2017). But such effects will depend strongly on local climate conditions, and only be important during dry weather conditions. This should be considered in predictive modeling of reindeer pasture resources. For example, the predicted near-future climate changes are for warmer and wetter weather for wild reindeer areas in Western Europe, i.e. south Norway, as recordings already suggest (Hanssen-Bauer et al. 2009).

Lichens can colonize most terrestrial habitats and are functionally important in many ecosystems. Their metabolically active growth periods are restricted to periods when the thallus is hydrated from atmospheric water sources, both rain, fog and high relative humidity (e.g. Jonsson Čabrajič et al. 2010). The water content in poikilohydric lichen increases rapidly on contact with sources of liquid water (e. g. Lange et al. 1986; Coxson 1988). A dry lichen can quickly absorb from 3 to 35 times its weight in water (Kershaw 1972; Kershaw 1985; Nash 2008). Rates of water loss are slower (de Vries and Watling 2008; Jonsson et al. 2008), but loss of water vapor to the air may occur rapidly during warm and dry days (Brown 1963). Thus lichens are characterized by frequent cycles of wetting and drying, which may even be a prerequisite for the long-term functioning of lichen metabolism (Honegger 1991). Optimum humidity for growth is between 40 and $70 \%$, but lichen tolerate irregular and extended periods of severe desiccation, for up to 9 months for some species (Kershaw 1972; Kershaw 1985; Nash 2008). Dry lichens can survive wide extremes of temperature, radiation and drought in the cold environments they often inhabit, but will be vulnerable to reindeer trampling. Anecdotal observations and early studies suggested that humidity is an important factor determining lichen elasticity (Hirsch et al. 1911; Pegau 1970). The amount of water in the lichen podetia vary with the air humidity, but we have demonstrated that the relationship between air humidity and lichen elasticity is not linear. Importantly, there is a rapid gain of elasticity with higher levels of humidity, e. g. 70\% $\mathrm{RH}$, meaning that humid, but not necessarily rainy days, are crucial for increasing trampling resilience in lichen. There was also a particularly marked increase in water weight gain up to $100 \% \mathrm{RH}$. We suspect this relationship at least to some extent related to the methods employed. For humidity up to 95\% RH, all samples were acclimatized in the environmental chamber. For $100 \%$ humidity, i.e. rain, we necessarily had to expose the samples to water directly. They were soaked in water and drained $10 \mathrm{~min}$ prior to testing. Thus the higher gained weight of these samples to an extent probably also reflect additional water adsorbed, and water droplets caught in the lichen branch structures.

The effects of trampling by reindeer on lichen has previously rarely been systematically studied and quantified, though some rather anecdotal studies or speculations indeed suggested the effects could be considerable and negative (Pegau 1970; Kumpula et al. 2011). Gaare and Skogland (1975) stated that reindeer 'spill' up to 10 times as much lichen as they actually consume. This 'spill factor' has later been adjusted to a factor of 2-10 (Bjerketvedt et al. 2015). Wastage estimates mainly based on these studies, are also included in reindeer population/bioeconomic models, but mainly for forested, i.e. less exposed ecosystems presumably more resilient to trampling effects. These have been nonlinear wastage factor functions with 'relative loss' values ranging from 0.5 to 4.5 depending on density of lichen and season (Moxnes et al. 2001; Tahvonen et al. 2014; Pekkarinen et al. 2017). Heggenes et al. (2017) experimentally documented that reindeer trampling can be a major factor, potentially generating considerably more trampling volume loss of lichen than lichen volume eaten by reindeer, if trampling occurs during dry weather. It should, however, also be noted that grazing and trampling may benefit lichen growth. Although lichen are slow growing (Kershaw 1985; Crittenden 2000), they also need to be regularly grazed and/ or trampled to have maximal growth (Gaare and Skogland 1980; Gaare et al. 1999). Lichen mats that remain un-grazed or untouched for 30 years or more start to rot as much at the bottom as they grow on top, so the annual biomass production slows down and approaches zero, whereas maximum growth may be at lichen mat thickness 2-4 cm (Gaare et al. 1999). Moreover, lichen fragmentation, for example by trampling, facilitates lichen dispersion and clonal growth (e.g. Kershaw 1985).

Here, we also document a consistent interaction between species and humidity. In particular, $F$. nivalis tended to be more variable and more resistant to higher trampling pressures, compared to Cladonia spp. Lichen consists of many species, but these two may constitute the most important lichen forage for tundra reindeer (Gaare and Skogland 1975; Danell et al. 1994). These are the preferred pastures wintertime (Skogland 1984), and the species C. stellaris, $C$. rangiferina and $C$. arbuscula, as well as $F$. nivalis and $F$. cucullata, are the most abundant, but with rather different 
morphologies. Flavocetraria spp. have a flat, bushy thallus with more band-like podetia up to $6 \mathrm{~cm}$ but usually shorter. Cladonia spp. on the other hand, have a generally more erect, tufted thallus with more narrow and rounded podetia 5-15 cm and curved. Consequently, they are more susceptible to trampling (Bayfield et al. 1981), and as indicated by the results reported here, have different elasticity response to humidity. With their more band-like podetia and thinner mats, Flavocetraria spp. appear to be more resilient to trampling than Cladonia spp. with increasing humidity.

\section{Regained height}

Regained height was most pronounced immediately after pressure release, and was limited or absent thereafter, corroborating preliminary results previously reported (Heggenes et al. 2017). However, in our study, the regain was generally more modest. We measured regained height also in the dry 25\% RH, whereas Heggenes et al. (2017) found that hoof-trampling incurred a permanent volume loss in dry lichen with little regain. Two factors probably contributed to these differences. First, our $10.5 \mathrm{~cm}$ diameter circular flat piece of plywood primarily made to test lichen resistance and elasticity, also implied a 'snowshoe' effect relative to an actual reindeer hoof. A hoof's uneven underside involves more crushing and shear stress on the substrate relative to a 'snowshoe', as documented by a typical reindeer footprint on soft substrates. Secondly, we exerted gradually stronger pressure. Reindeer trampling is an immediate, strong impact.

How may this be affected by predicted near-future climate change? So far it has resulted in increasing temperatures and precipitation in Scandinavian alpine areas, trends assumed to continue in the future (Hanssen-Bauer et al. 2015). A milder climate may disfavor slow-growing ground lichen which benefit in chionophobic habitats with frost (Odland and Munkejord 2008; Tømmervik et al. 2012). Lichen hydration depends on interaction effects of increased precipitation and higher air temperatures, particularly during the frost free season. An increase of rain-on-snow events will keep the reindeer from foraging on lichen, whereas more summer precipitation may improve growth rates (Tømmervik et al. 2012) and reduce trampling effects. Despite increasing precipitation, ecological studies in alpine areas show an increasing drying of alpine vegetation communities and ecosystems (Griggs and Noguer 2002; Virtanen et al. 2003; Kullman 2010; Sandvik and Odland 2014). This indicates that lichens will be dehydrated for longer periods in the future as a result of higher evaporation. Consequently, if reindeer graze lichen during such periods, trampling loss of lichen, will likely increase.

In conclusion, relative humidity is clearly a very important factor, and probably the most important factor, influencing lichen elasticity, and thereby their resilience to trampling. This effect was non-linear, requiring relatively high humidity, as elasticity increased rapidly at $70 \% \mathrm{RH}$ and higher. There was also an effect of lichen species, related to their growth and branch forms, whereas temperature appeared to be of minor importance within the range tested.

Acknowledgements Open Access funding provided by University Of South-Eastern Norway. We are grateful to Frode Bergan for providing help with developing the technical installations used in the experiments, and to Prof. emeritus Dr. Howard Parker for copy-editing and proof reading the manuscript.

\section{Compliance with ethical standards}

Conflict of interest There were no conflict of interest associated with this work.

Open Access This article is licensed under a Creative Commons Attribution 4.0 International License, which permits use, sharing, adaptation, distribution and reproduction in any medium or format, as long as you give appropriate credit to the original author(s) and the source, provide a link to the Creative Commons licence, and indicate if changes were made. The images or other third party material in this article are included in the article's Creative Commons licence, unless indicated otherwise in a credit line to the material. If material is not included in the article's Creative Commons licence and your intended use is not permitted by statutory regulation or exceeds the permitted use, you will need to obtain permission directly from the copyright holder. To view a copy of this licence, visit http://creativecommons.org/licenses/by/4.0/.

\section{References}

Akaike H (1974) A new look at the statistical model identification. IEEE Trans Autom Control 19:716-723. https://doi. org/10.1109/TAC.1974.1100705

Arnold TW (2010) Uninformative parameters and model selection using Akaike's information criterion. J Wildl Manage $74: 1175-1178$

Bayfield NG, Urquhart UH, Cooper SM (1981) Susceptibility of 4 species of Cladonia to disturbance by trampling in the Cairngorm Mountains. Scotl J Appl Ecol 18:303-310. https://doi. org/10.2307/2402497

Bjerketvedt DK, Heggenes J, Odland A (2015) Hvor mange kg lav forbruker 10000 reinsdyr på Hardangervidda per år? VILLREINEN 2015:65-69

Blum OB (1973) Water relations. In: Ahmadjian V, Hale ME (eds) The lichens. Academic Press, New York, pp 381-400

Brown RJE (1963) Influence of vegetation on permafrost. In: Woods KBE (ed) Permafrost. International conference: proceedings, vol Publ. 1287. National academy of Sciences-national research council, Washington, pp 20-25

Burnham KP (2002) Model selection and multimodel inference : a practical information-theoretic approach, 2nd edn. Springer, New York

Coxson D (1988) Recovery of net photosynthesis and dark respiration on rehydration of the lichen Cladina mitis, and the influence of prior exposure to sulphur dioxide while desiccated. New Phytol 108:483-487

Crittenden P (2000) Aspects of the ecology of mat-forming lichens. Rangifer 20:127-139 
Cumming DHM, Cumming GS (2003) Ungulate community structure and ecological processes: body size, hoof area and trampling in African savannas. Oecologia 134:560-568. https://doi. org/10.1007/s00442-002-1149-4

Danell K, Utsi PM, Palo TR, Eriksson O (1994) Food plant selection by reindeer during winter in relation to plant quality. Ecography $17: 153-158$

de Vries MC, Watling JR (2008) Differences in the utilization of water vapour and free water in two co-occurring foliose lichens from semi-arid southern Australia. Austral Ecol 33:975-985. https://doi.org/10.1111/j.1442-9993.2008.01868.x

Falldorf T, Strand O, Panzacchi M, Tømmervik H (2014) Estimating lichen volume and reindeer winter pasture quality from Landsat imagery. Remote Sens Environ 140:573-579

Gaare E, Skogland T (1975) Wild reindeer food habits and range use at Hardangervidda. In: FEW (ed) Eological studies 17 Fennoscandian tundra ecosystems part 2. Springer, Berlin, pp 195-205

Gaare E, Skogland T (1980) Lichen-reindeer interaction studied in a simple case model. In: Reimers E, Gaare E, Skjenneberg S (eds) Proceedings of 2nd International Reindeer/Caribou Symposium, Røros, Norway, 1979. Direktoratet for vilt og ferskvannsfisk, Trondheim, pp 47-56

Gaare E, Ihse M, Kumpula J (1999) Beiteslitasje, tråkk og forurensninger. In: Dahle HK, Danell Ø, Gaare E, Nieminen M (eds) Reindrift i Nordvest-Europa 1998: biologiske muligheter og begrensninger. Nordisk Ministerråd, København, pp 57-65

Griggs DJ, Noguer M (2002) Climate change 2001: the scientific basis. Contribution of working group I to the third assessment report of the intergovernmental panel on climate change. Weather 57:267-269

Hansen BB, Aanes R, Herfindal I, Saether BE, Henriksen S (2009) Winter habitat-space use in a large arctic herbivore facing contrasting forage abundance. Polar Biol 32:971-984. https://doi. org/10.1007/s00300-009-0597-2

Hanssen-Bauer I et al. (2009) Klima i Norge 2100. Bakgrunnsmateriale til NOU Klimatilplassing Report Norwegian Climate Center, p 148

Hanssen-Bauer I et al. (2015) Klima i Norge 2100 Kunnskapsgrunnlag for klimatilpasning oppdatert i 2015 vol 2/2015. Norwegian Climate Service Center, Oslo

Heggenes J, Odland A, Chevalier T, Ahlberg J, Berg A, Larsson H, Bjerketvedt DK (2017) Herbivore grazing — or trampling? Trampling effects by a large ungulate in cold high-latitude ecosystems. Ecol Evol 7:6423-6431

Hirsch JL, Lægreid O, Aasberg G (1911) Indstilling fra Fjeldbeitekomiteen om Hardangerviddens Utnyttelse. Landbruksdepartementet, Centraltrykkeriet Kristianina

Holtmeier F-K (2015) Animals' influence on the landscape and ecological importance-natives, newcomers homecomers. Springer, Dordrecht

Honegger R (1991) Functional aspects of the lichen symbiosis. Annu Rev Plant Biol 42:553-578

Jonsson AV, Moen J, Palmqvist K (2008) Predicting lichen hydration using biophysical models. Oecologia 156:259-273

Jonsson Čabrajič AV, Moen J, Palmqvist K (2010) Predicting growth of mat-forming lichens on a landscape scale-comparing models with different complexities. Ecography 33:949-960. https://doi. org/10.1111/j.1600-0587.2009.06079.x

Kershaw KA (1972) The relationship between moisture content and net assimilation rate of lichen thalli and its ecological significance. Can J Bot-Rev Can Bot 511:543-555

Kershaw KA (1985) Physiological ecology of lichens. Cambridge University Press, Cambridge, Cambridge
Kjørstad M et al (2017) Miljøkvalitetsnorm for villrein. Forslag fra en ekspertgruppe vol 1400. Norwegian Institute for Nature Research, Trondheim

Klein DR, Shulski M (2011) The role of lichens, reindeer, and climate in ecosystem change on a Bering Sea island. Arctic. https://doi. org/10.14430/arctic4124

Kojola I, Helle T, Niskanen M, Aikio P (1995) Effects of lichen biomass on winter diet, body mass and reproduction of semi-domesticated reindeer Rangifer tarandus in Finland. Wildl Biol 1:33-38

Kudo G (1991) Effects of snow-free period on the phenology of alpine plants inhabiting snow patches. Arctic Alp Res 23:436-443

Kullman L (2010) A richer, greener and smaller alpine world: review and projection of warming-induced plant cover change in the Swedish Scandes. Ambio 39:159-169

Kumpula J (2001) Winter grazing of reindeer in woodland lichen pasture: effect of lichen availability on the condition of reindeer. Small Ruminant Res 39:121-130

Kumpula J, Stark S, Holand O (2011) Seasonal grazing effects by semidomesticated reindeer on subarctic mountain birch forests. Polar Biol 34:441-453. https://doi.org/10.1007/s00300-010-0899-4

Lange O, Kilian E, Ziegler H (1986) Water vapor uptake and photosynthesis of lichens: performance differences in species with green and blue-green algae as phycobionts. Oecologia 71:104-110

Lezama F, Paruelo JM (2016) Disentangling grazing effects: trampling, defoliation and urine deposition. Appl Veg Sci 19:557-566. https ://doi.org/10.1111/avsc. 12250

Ludvikova V, Pavlu VV, Gaisler J, Hejcman M, Pavlu L (2014) Long term defoliation by cattle grazing with and without trampling differently affects soil penetration resistance and plant species composition in Agrostis capillaris grassland. Agric Ecosyst Environ 197:204-211. https://doi.org/10.1016/j.agee.2014.07.017

Lundqvist H (2003) Review of factors affecting productivity of reindeer husbandry. Swedish University of Agricultural Sciences, Department of Animal Breeding and Genetics, Uppsala

Matwiejuk A (2000) Water content in terricolous lichens. Acta Soc Bot Poloniae 69:55-63

Mazerolle MJ (2017) AICcmodavg: model selection and multimodel inference based on (Q)AIC(c). R package version 2.1-1. https:// cran.r-project.org/package=AICcmodavg. Accessed 29 Mar 2020

Merkgren G (1971) De nordliga hjortdjurens vinterproblem—en ekologisk õversikt. Flora 5:174-185

Moxnes E, Danell O, Gaare E, Kumpula J (2001) Optimal strategies for the use of reindeer rangelands. Ecol Model 145:225-241. https:// doi.org/10.1016/s0304-3800(01)00393-3

Mudongo EI, Fynn RWS, Bonyongo MC (2016) Role of herbivore impact and subsequent timing and extent of recovery periods in rangelands. Rangel Ecol Manage 69:327-333. https://doi. org/10.1016/j.rama.2016.04.003

Nash TH (2008) Lichen biology, 2nd edn. Cambridge University Press, Cambridge, pp 5-6

Nellemann C (1996) Terrain selection by reindeer in late winter in central Norway. Arctic 49:339-347

Nellemann C, Vistnes I, Jordhoy P, Stoen OG, Kaltenborn BP, Hanssen F, Helgesen R (2010) Effects of recreational cabins, trails and their removal for restoration of reindeer winter ranges. Restor Ecol 18:873-881. https://doi.org/10.1111/j.1526-100X.2009.00517.x

Odland A, Munkejord HK (2008) The importance of date of snowmelt for the separation of different oligotrophic and mesotrophic mountain vegetation types in Southern Norway. Phytocoenologia 38:3-21. https://doi.org/10.1127/0340-269x/2008/0038-0003

Odland A, Sundst $\varnothing 1$ SA, Bjerketvedt DK (2018) Alpine lichen-dominated heaths: ecology, effects of reindeer grazing, and climate change. A review. Oecol Montana 27:30-50

Pegau RE (1970) Effect of reindeer trampling and grazing on lichens. J Range Manage 23:95-000. https://doi.org/10.2307/3896107 
Pekkarinen AJ, Kumpula J, Tahvonen O (2017) Parameterization and validation of an ungulate-pasture model. Ecol Evol 7:8282-8302

Punsvik T, Jaren V (2006) Målrettet villreinforvaltning—skjøtsel av bestander og bevaring av leveonmråder. Tun Forlag, Oslo

Rosenthal G, Schrautzer J, Eichberg C (2012) Low-intensity grazing with domestic herbivores: a tool for maintaining and restoring plant diversity in temperate Europe. Tuexenia 31:167-205

Sandvik SM, Odland A (2014) Changes in alpine snowbed-wetland vegetation over three decades in northern Norway. Nordic J Bot 32:377-384

Skarin A, Ahman B (2014) Do human activity and infrastructure disturb domesticated reindeer? The need for the reindeer's perspective. Polar Biol 37:1041-1054. https://doi.org/10.1007/s0030 0-014-1499-5

Skogland T (1978) Characteristics of snow cover and its relationship to wild mountain reindeer (Rangifer tarandus-tarandus) feeding stratergies. Arct Alp Res 10:569-579. https://doi. org/10.2307/1550680

Skogland T (1984) Wild reindeer foraging-niche organization. Holarct Ecol 7:345-379

Skree O (1975) CO2 exchange in Norwegian tundra plants studied by infrared gas analyzer technique. In: Wielgolaski FE (ed) Fennoscandian tundra ecosystems. Springer, Berlin, pp 168-183

Storeheier PV, Mathiesen SD, Tyler NJC, Olsen MA (2002) Nutritive value of terricolous lichens for reindeer in winter. Lichenologist. https://doi.org/10.1006/lich.2002.0394

Strand O, Bevanger K, Falldorf T (2006) Reinens bruk av Hardangervidda. Sluttrapport fra Rv7-prosjektet Norsk Institutt for Naturforskning, Trondheim
Tahvonen O, Kumpula J, Pekkarinen AJ (2014) Optimal harvesting of an age-structured, two-sex herbivore-plant system. Ecol Model 272:348-361. https://doi.org/10.1016/j.ecolmodel.2013.09.029

Tømmervik H, Bjerke JW, Gaare E, Johansen B, Thannheiser D (2012) Rapid recovery of recently overexploited winter grazing pastures for reindeer in northern Norway. Fungal Ecol. https://doi. org/10.1016/j.funeco.2011.08.002

Venables VM, Smith DM (2012) An introduction to R. Notes on R: a programming environment for data analysis and graphics version 2.15.2. R Core Team

Virtanen R, Eskelinen A, Gaare E (2003) Long-term changes in alpine plant communities in Norway and Finland. In: Alpine biodiversity in Europe. Springer, pp 411-422

Vistnes I, Nellemann C (2008) The matter of spatial and temporal scales: a review of reindeer and caribou response to human activity. Polar Biol 31:399-407. https://doi.org/10.1007/s0030 0-007-0377-9

Vistnes I, Nellemann C, Jordhøy P, Strand O (2004) Effects of infrastructure on migration and range use of wild reindeer. J Wildl Manage 68:101-108

Publisher's Note Springer Nature remains neutral with regard to jurisdictional claims in published maps and institutional affiliations. 